\title{
Fruit quality and occurrence of mildew in Niagara Rosada grown under plastic cover and defoliation rates
}

\author{
Solivan Rosanelli ${ }^{1}$, Fabíola Villa ${ }^{1 * \mathbb{D}}$, Daniel Fernandes da Silva ${ }^{l}$, \\ Maria Cristina Copello Rotili ${ }^{1}$, Tatiane Eberling ${ }^{1}$
}

10.1590/0034-737X202067020007

\begin{abstract}
The purpose of this study was to evaluate the agronomic behavior of the Niagara Rosada variety cultivated under plastic cover, using defoliation intensities, and its influence on the Plasmopara viticola. The experiment was conducted in Francisco Beltrão, PR, Brazil, in a vineyard of Niagara Rosada variety in a trellised system during the 2016/2017 and 2017/2018 crop seasons. The experimental design consisted of randomized blocks, in a 5 × 2 factorial scheme being five percentages of defoliation $(0 \%, 10 \%, 20 \%, 30 \%$ and $40 \%$,) and use of coverage (with and without coverage), with three blocks of three useful plants per experimental plot. The temperature, air humidity and incidence of mildew on the bunches and leaves were recorded. At the end of each crop station, three bunches per plant of each plot were evaluated for the fresh biomass of the bunches, length and width of the bunches, soluble solids content, $\mathrm{pH}$, number of bunches per plant, production, and productivity. It was concluded that the plastic cover associated with the environmental conditions, and phytosanitary management can favor the physical-chemical quality and reduce the severity of the mildew in the Niagara Rosada variety providing greater production and productivity. The use of defoliation does not favor the cultivation of this variety in southwestern Paraná.
\end{abstract}

Keywords: Vitis labrusca L.; plasticulture; leaf pruning; Plasmopara viticola.

\section{INTRODUCTION}

Brazilian viticulture presents great diversity, with more than 120 cultivars of Vitis vinifera L. and 40 cultivars of American grapes, spread from Rio Grande do Sul to Rio Grande do Norte (Camargo et al., 2011). In Paraná state, the area harvested is $4,170 \mathrm{ha}$, with a production of 59,151 metric tons and an average yield of $14,185 \mathrm{~kg} \mathrm{ha}^{-1}$, which is lower than the Brazilian average (IBGE, 2018; Bueno et al., 2017).

The production of rustic vines is an activity that generates employment and income, thereby helping man settle in the field and generate wealth in the regions where it is consolidated. It corresponds to $20 \%$ of the total cultivated area with table grapes in the state of Paraná, Brazil (Zarth et al., 2011), representing a large market, mainly thanks to its potential to grow in regions of the state that are traditionally known for the predominance of grain and meat production, such as the southwestern region of the state.
As an American table grape (or a rustic grape), Niagara Rosada variety is an alternative, with a marked presence in the vineyards due to its low crop treatment requirement, great acceptance of fresh products in the market, rusticity, its ability to be grown in regions with a humid climate, in addition to low production costs compared to fine table grapes (Camargo et al., 2011).

Notwithstanding, Vitis labrusca cultivation occurs during the rainy season, when the temperature and relative humidity of the air are higher, favoring the appearance of diseases such as mildew, which become a limiting factor to viticulture, in the event that appropriate measures of control are not adopted (Kishino et al., 2007).

Downy mildew is caused by the Plasmopara viticola (Berk. \& M. A. Curtis) Berl. and De Toni, being responsible for damages in the Brazilian viticulture as well as in other wine regions in the world. In order minimize the incidence of mildew, in regions where the harvest occurs in the period

Submitted on October $21^{s t}, 2018$ and accepted on February $29^{\text {th }}, 2020$.

${ }^{1}$ Universidade Estadual do Oeste do Paraná, Centro de Ciências Agrárias, Marechal Cândido Rondon, Paraná, Brazil. agro_soli@hotmail.com; fvilla2003@hotmail.com; daniel_eafi@yahoo.com.br; mcrotili@hotmail.com; tatiane_eberling@hotmail.com

*Corresponding author: fvilla2003@ hotmail.com 
of higher humidity throughout the year, plastic covers may be used on vineyard lines. The main advantages are the reduction of phytosanitary treatments, production of higher-quality fruits, savings in inputs, and soil conservation, thereby enabling an increase in productivity and obtaining bunches with marketing standards (Yamamoto et al., 2012).

In a study developed by Comiran et al. (2012), the use of plastic cover changes the microclimate of vineyards, reducing photosynthetically active radiation incident on the plants and increasing the temperature of the air in the daytime period. The same authors report that the development of Niagara Rosada variety under plastic cover is accelerated until maturation and delayed thereafter. Compared to open-air, the harvest period of the grapes is prolonged, and leaf fall is delayed. There is also an increase in the diameter and mass of the berries, as well as fruit yield.

Another practice that can be used to minimize the incidence of downy mildew is defoliation, with the aim of favoring aeration in the region of the inflorescences and bunches, thereby providing better conditions for maturation (Miele et al., 2009). Souza et al. (2012) found that the presence of 5,10 and 15 leaves in the production branch provided a longer berry volume and did not interfere in the production of the Superior Seedless cultivar.

Despite the promising results with the use of cover and defoliation in relation to the control of downy mildew, the adoption of these techniques in the vines causes changes in the microclimate, modifying solar radiation, air temperature and humidity, rainfall on the plants, and damages caused by the wind (Roberto et al., 2011), which may affect the physical-chemical quality of the fruits. This evaluation should be carried out in detail in each growing region, as the characterization of grape production is a relevant factor that shows producers in the region the performance and yield of the crop under local conditions (Neis et al., 2010).

In view of the above, the purpose of this study was to evaluate the agronomic behavior of the Niagara Rosada variety cultivated under plastic cover, using defoliation rates, and its influence on the Plasmopara viticola, in order to improve fruit quality in the southwestern region of Paraná, Brazil.

\section{MATERIAL AND METHODS}

The experiment was conducted in two commercial crop seasons, 2016/17 and 2017/18, in a commercial orchard in Francisco Beltrão, Paraná, Brazil, located at the geographic coordinates of $26^{\circ} 08^{\prime} 44^{\prime \prime}$ South (latitude), $53^{\circ} 14^{\prime} 34^{\prime \prime}$ West (longitude), with $650 \mathrm{~m}$ above the sea. The climate, according to the Köppen classification is $C f a$, characterized as subtropical humid with a mesothermal climate (Alvares et al., 2014). The mean minimum temperature is $14^{\circ} \mathrm{C}$, the mean maximum temperature is 26 ${ }^{\circ} \mathrm{C}$, and the mean annual rainfall is $2,046 \mathrm{~mm}$, distributed across 131 days during the year, with a mean sunshine of 2,331 hours of light. Soil is classified as Dystroferric Red Latossol with a clayey texture, being deep and very weathered, with low fertility (Embrapa, 2006).

The orchard is formed by five-year vines of Niagara Rosada variety (Vitis labrusca L.), grafted on the "Paulsen 1103 " rootstock for adapting to clayey soils due to high rooting and resistance to mildew, fusariosis and phylloxera. The management system consists of a trellis that adapts to the placement of the plastic and provides the distribution of the branches and leaves, making harvest easier.

A $3 \times 2$ meters spacing was used for a total of 1,666 plants per hectare. The experimental design consisted of randomized blocks, in a $5 \times 2$ factorial scheme (percentage of defoliation $\mathrm{x}$ coverings), containing 3 replicates per treatment and 5 plants in each plot, using the three central plants, totaling 90 plants evaluated. In the main plots, cover was allocated (with and without cover), as well as the defoliation percentages in the subplots.

The coverage systems used were traditional uncovered and covered, with low-density polyethylene, with 100 microns in thickness and with protection against ultraviolet rays, with a width of $2.20 \mathrm{~m}$. The plastic film was fixed in iron arches stuck in treated eucalyptus stands, spaced every 3 meters and positioned at a distance of $0.5 \mathrm{~m}$ above the canopy of the plants. The grapevines are completely surrounded by a green Lahuman ${ }^{\circledR}$ net, $1.5 \mathrm{~m}$ in width, in order to avoid the presence of insects and birds.

Dry pruning was performed on August 25, 2016 and August 28, 2017, using short pruning, leaving up to 3 buds per spur and promoting the renewal of the crop and the balance of the vegetative/productive part. On November 11, 2016 and November 2, 2017, summer pruning and defoliation were performed. At these dates, the plant reached peak vegetative growth, with its branches reaching the last wire of the structure. Defoliation occurred according to the treatments $0 \%, 10 \%, 20 \%, 30 \%$ and $40 \%$, followed by a counting of the number of leaves and leaving the respective foliar percentages.

The phytosanitary treatments were winter treatment, in July in the two years, using a lime-sulfur solution applied for the preventive control of fungi, lichens, mosses, and insects. In addition to this operation, fungicide applications were made using azoxystrobin, fosetyl, propineb, mancozeb, difenoconazole, thiophanate-methyl, and metalaxyl-M, according to the recommendation for the crop.

Two fertilizations with alternating potassium nitrate and calcium nitrate were made, started after fruit growth, 
following the recommendation of the nutrition program Yara Brasil 2008/2 (Yara, 2008). Irrigation was by drip system in the vineyard always kept clear. The harvest was manual and transported with the help of a tractor. For the monitoring of the temperature and relative humidity of the air, dataloggers were placed, one of which was placed under the cover and the other, in an open place, collecting the data every hour, during the entire production cycle in crops (Figure 1A and 1B).

From the moment of the pruning and beginning of the shoots onwards, bi-weekly monitoring of the incidence of mildew was carried out, including an observation of the appearance of the first visible symptoms within the usable area of the plot, in the leaves and bunches.

When the berries reached uniform pink coloration, with a total soluble solids content of more than $14^{\circ}$ Brix, as described in Normative Instruction n. 1 of February 1, (Brasil, 2002), fruit evaluations were performed. The bunches were harvested with the aid of harvest and fruit thinning shears of the brand Tramontina ${ }^{\circledR}$, being then packed in plastic bags properly labeled and transported in low plastic boxes in air-conditioned environment for analysis at the Food Technology Laboratory. Three bunches of each of the three useful plants component of each plot were separated for determination of fresh bunch biomass, bunch length and width, soluble solids (SS) $\left({ }^{\circ} \mathrm{Brix}\right)$, and $\mathrm{pH}$.

A semi-analytical balance ( $\mathrm{g}$ ) was used to determine the fresh biomass of the bunches. The length and width of the bunches were measured using a caliper and a measuring tape $(\mathrm{cm})$. For the determination of SS $\left({ }^{\circ}\right.$ Brix $)$, a digital bench refractometer (Reichert $\mathrm{r}^{2}$ mini Digital Handheld Refractometer) was used at a temperature of $20^{\circ} \mathrm{C}$. To determine the $\mathrm{pH}, 20 \mathrm{~mL}$ of juice was transferred to a $100 \mathrm{~mL}$ beaker, and the sample was read with the digital $\mathrm{pH}$ meter (IAL 2008).

The number of bunches, yield and productivity of the vineyard were also determined. The production $(\mathrm{kg}$ plant ${ }^{1}$ ) was determined from the fresh biomass of the bunches harvested in each plant multiplied by the number of bunches. Productivity $\left(\mathrm{kg} \mathrm{ha}^{-1}\right)$ was determined based on yield multiplied by the number of plants per hectare.

The data obtained were analyzed for normality by the Shapiro-Wilk test and submitted to analysis of variance, and significant differences by the Tukey test at 5\% probability of error for the qualitative variables. The results obtained for the quantitative variables were then submitted to polynomial regression analysis, with the aid of the statistical program Sisvar (Ferreira, 2011).

\section{RESULTS AND DISCUSSION}

There was a significant interaction between defoliation and cover only for $\mathrm{pH}$, in the $2016 / 17$ crop season, with significance for vines that received coverage, within defoliation levels, and at intensities of 30 and $40 \%$, the $\mathrm{pH}$ of the fruits showed (Figure 2). In the 2017/18 crop season, none of the variables analyzed showed a significant interaction between the factors studied.

The acidity found in berries of vines is a result of the organic acids present in their composition and physicalchemical changes occurring in their maturation process, due to the degradation of the acids during the process of fruit respiration. In the case of grapes, acidity is also affected by the fermentative effect of certain yeasts, which may produce organic acids, in addition to the dissolution of minerals and acids released from their skin and pulp (Miele et al., 2009).

It can be observed in this study that the application of defoliation is efficient only when the vines are cultivated under cover, in which case the application of $30 \%$ and $40 \%$ defoliation allows a rise in $\mathrm{pH}$ by up to 3.05 , if the must is used for winemaking purposes. In contrast to these results, the cultivation of the Niagara Rosada variety without cover does not present differences in $\mathrm{pH}$, regardless of the level of defoliation.

Several hypotheses support the elevation of $\mathrm{pH}$ in vines grown under defoliation. According to Pötter et al. (2010), the development of defoliation, especially in leaves located near the bunches, as in this study, provide an increase in solar radiation, temperature and aeration in the production region, improving the coloring and maturation of the berries, besides reducing the incidence of diseases.

The development of defoliation allows the penetration of a greater intensity of solar radiation, which is of great importance, as it allows the synthesis of organic compounds, improving the organoleptic production and quality of the grape and raising its $\mathrm{pH}$ (Radünz et al., 2013). On the other hand, defoliation may act restricting the source of photoassimilates, so it should be carried out at the correct intensity, so that it does not act only to decrease the photosynthesizing leaf area (as occurred in up to $20 \%$ defoliation intensity), but rather allowing the incidence of solar radiation at the ideal intensity.

The change in the microclimate as a function of the defoliation can alter enzymatic activity in the fruit and thus increase the potassium content in the berries, leading to a $\mathrm{pH}$ rise influenced by the drop in acidity levels according to Fogaça et al. (2007).

Another hypothesis, which bases the higher $\mathrm{pH}$ on grape berries in which defoliation between $30 \%$ and $40 \%$ was carried out, is the best distribution of the photoassimilates, as the grafts that allow greater vigor of the canopy, such as 'Paulsen 1103' in studied plants, tend to extend the period of vegetative growth, delaying the accumulation of sugar in the fruits (Bettoni et al., 2013). Thus, the balance between the vegetative part and the 
A

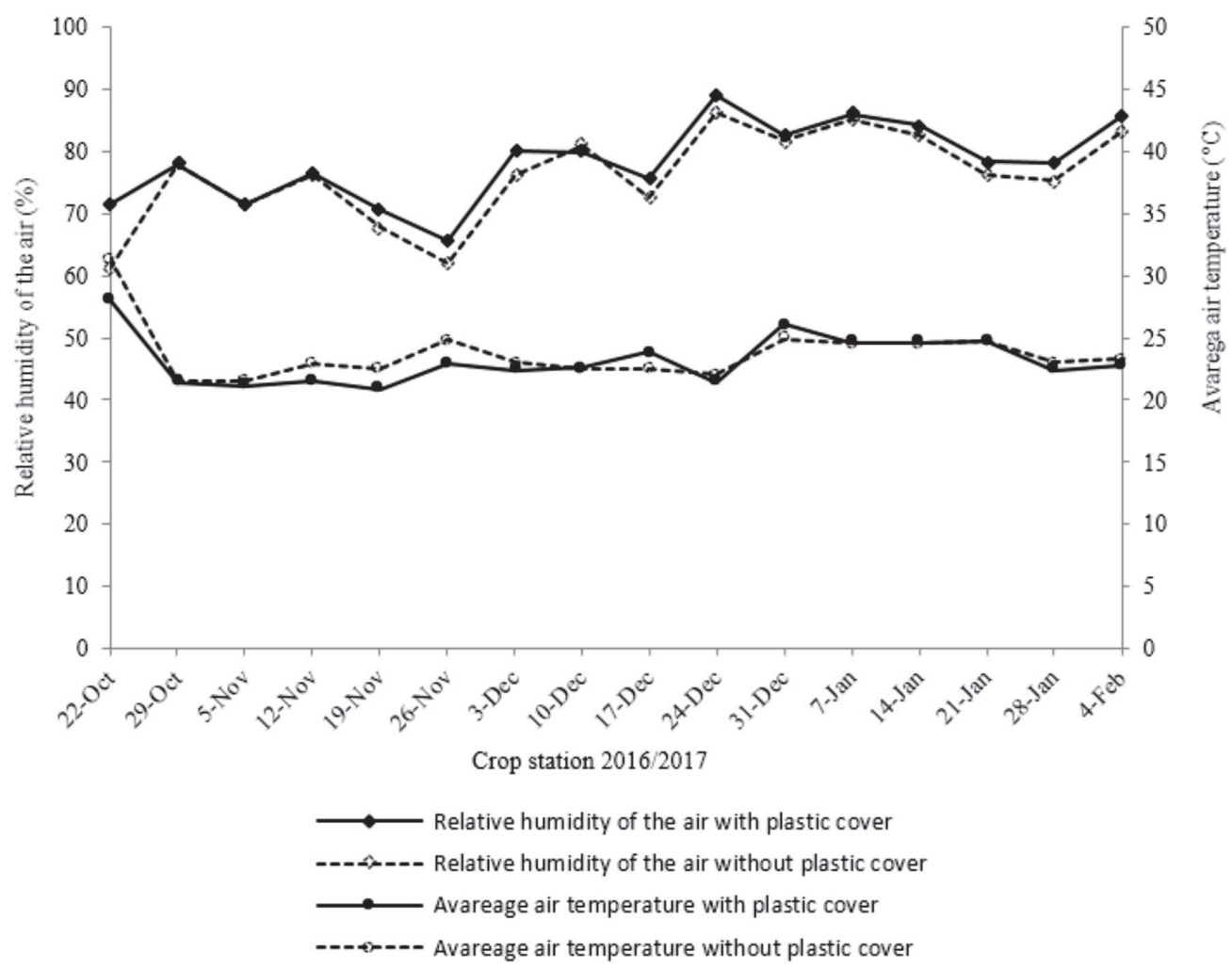

B
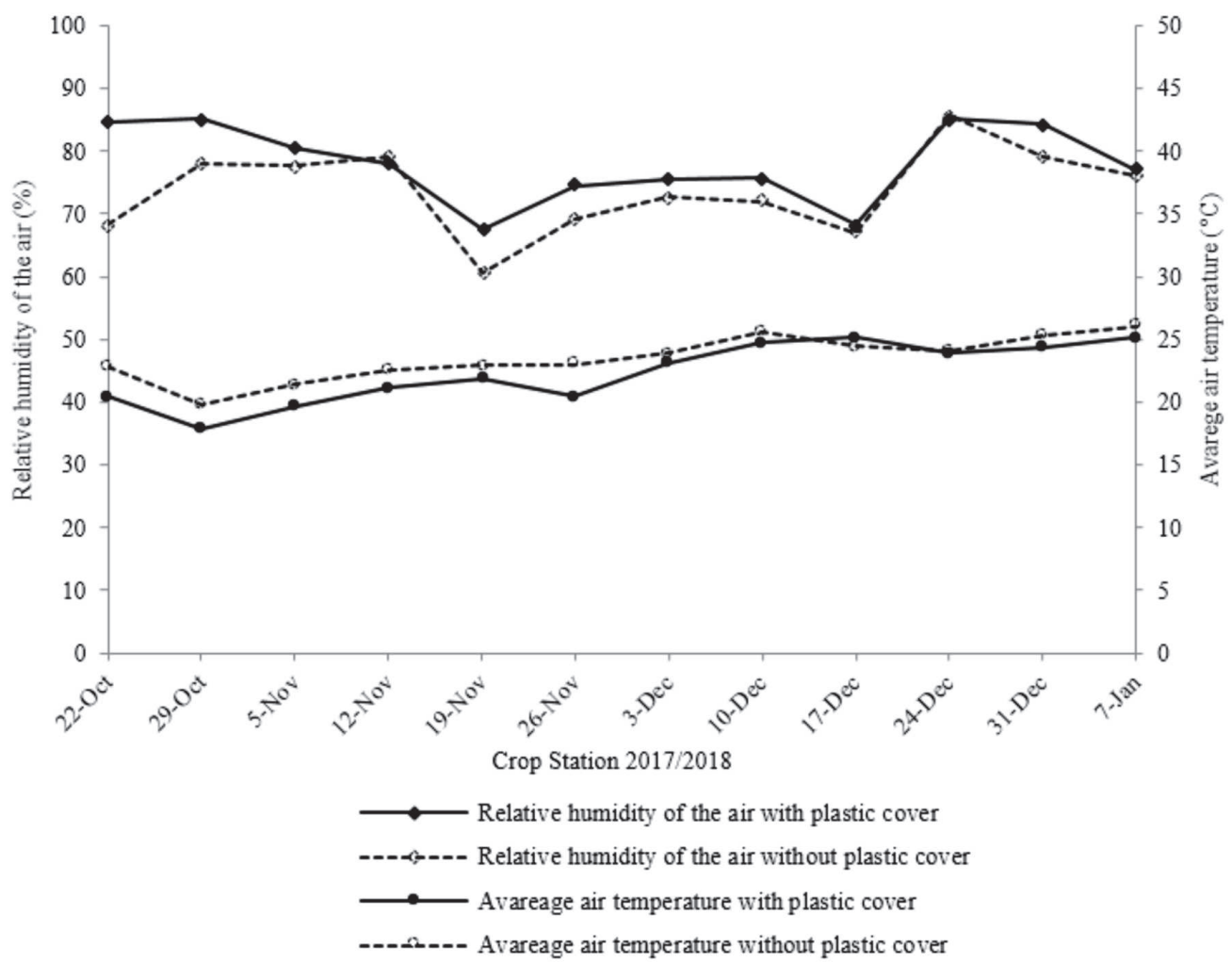

Figure 1: Weekly average of temperature and relative humidity of the air between pruning of production and harvest, in orchard of vines cv. Niagara Rosada, cultivated in Francisco Beltrão (PR), under two systems of cover and five intensities of defoliation, in the 2016/2017 (A) and 2017/2018 (B) harvests. Unioeste, Campus Marechal C. Rondon, PR. 2018.

Rev. Ceres, Viçosa, v. 67, n.2, p. 137-146, mar/apr, 2020 
yield, provided by the defoliation, favored redistribution of these assimilates.

In the 2017/18 crop season, the non-verification of the statistical significance for the $\mathrm{pH}$ levels, either between treatments related to cover or treatments related to defoliation, may be related to the higher rainfall index during the maturation period in relation to the previous crop season. Thus, the concentration of soluble solids synthesized at this stage was similar and quite diluted in the high moisture content of the fruits, which enabled similar expression of the organic acids in a similar way in all treatments, allowing no significant changes in the acidity of the berries. In addition to the amount of rainfall, the higher frequency of cloudy days during maturation may have reduced incident solar radiation, which affects the accumulation of sugars and indirectly influences $\mathrm{pH}$.

In general, despite the variations presented as a function of the treatments employed, the $\mathrm{pH}$ verified was satisfactory for Niagara Rosada variety. According to data from Maia \& Camargo (2012), this cultivar should have $\mathrm{pH}$ around 3.21. Thus, the variation between 2.82 and 3.05 found in this present study was slightly below that indicated for the variety.

Anzanello et al. (2011), when studying the Niagara, Concord, Cabernet Sauvignon and Merlot varieties at different levels of defoliation, concluded that the removal of leaves up to the height of the bunch at the beginning of ripening of the berries does not change the quantitative and qualitative variables of the fruits. The same authors also verified that, for Niagara and Concord, the defoliation performed above the bunches caused a delay in the maturation of the grapes, negatively affecting the physicalchemical characteristics of the fruits.

For the other analyzed variables, soluble solids content, bunch length and diameter and number of bunches per plant were significant only in the 2016/17 harvest, whereas for bunch biomass, yield and productivity, the significance can be verified in the two crop seasons, always favorable regarding treatment with coverage (Tables 1, 2, and 3).

For SS of the berries, higher values $\left(14.58^{\circ}\right.$ Brix $)$ were found in bunches of vines covered with plastic cover, compared to the uncovered system $\left(13.49^{\circ}\right.$ Brix) (Table 1$)$.

This higher soluble solids content is also reported by Yamamoto et al. (2012), in which the authors justify the higher SS content of the BRS Clara grapes grown from grapevines under transparent plastic in braided polyethylene (20\% shading) due to the greater photosynthetic capacity of plants in this condition, increasing the production of sugars in these fruits.

Reinforcing the results found, Comiran et al. (2012) state that, in plastic-coated environments in general, a reduction in the thermal amplitude occurs, which conditions the coloring processes and concentration of soluble solids in a positive way, as in the Vitis labrusca bunches reaching $22^{\circ} \mathrm{Brix}$. These results may be related to maturation time in different environments.

In the 2017/2018 crop season, the soluble solids content did not differ between treatments. The nonvariation in the soluble solids content in this crop may be related, among other factors, to the high water availability in the soil during maturation, which provides a higher water uptake, disfavoring the concentration of sugars in the berries (Yamamoto et al., 2012). Similarly, Detoni et al. (2007) and Chavarria et al. (2010) did not find a significant difference in the SS content in bunches of variety Romana, Cabernet Sauvignon and Moscato Giallo in LDPEcovered and uncovered vineyard.

For the number of bunches per plant, the result was significant for the use of cover in the 2016/2017 crop (Table 1) and only for application of defoliation in the $2017 / 2018$

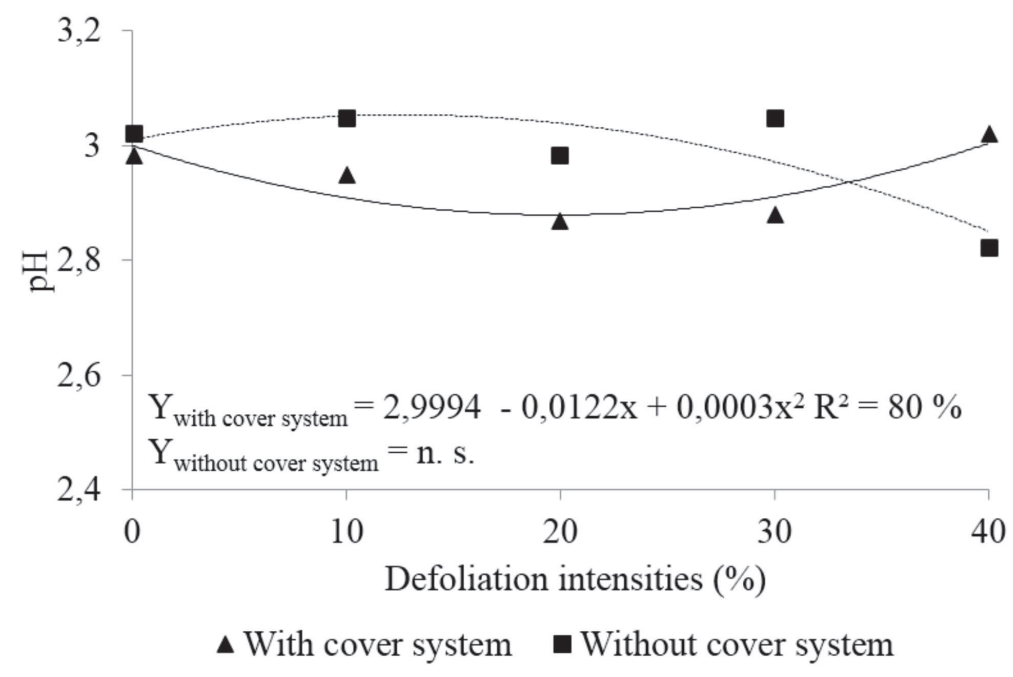

Figure 2: Mean $\mathrm{pH}$ values in bunches vines of bunches of Niagara Rosada variety cultivated in Francisco Beltrão, Paraná, under cover systems and defoliation intensities, in the 2016/2017 crop season. 
crop (Figure 3A). In the first harvest, the system with plastic cover showed 36.18 bunches per plant, differing statistically from the uncovered system, in which the yield was 32.67 bunches per plant. In the second year, uncovered grapevines stood out in relation to the those under cover, producing 38.73 , compared to 36.21 , not differing statistically.

It was also observed that plants without the use of defoliation produced on average 40.14 bunches in 2017/18 crop (Figure 3A), presenting superiority compared to the others plants, where there was defoliation. The seasonal variation in the fruiting capacity of buds may be due to climatic factors, cultural practices or diseases that affect the vines. The most often studied climates include light, temperature, and water restriction, all influenced by the use and plastic cover.

The installation of the plastic cover on the vineyard promotes changes in the structure and physiology of the plants, altering thermal and water conditions of the soilplant-atmosphere system and the distribution patterns of solar radiation in the canopy (Cardoso et al., 2010). This change in the microclimate next to the canopy of the vines may have influenced the sprouting of the buds, consequently leading to a larger production of bunches under cover in the 2016/17 crop season, as shown in Table 1 .

Differences in numbers of bunches per plant were also found by Chavarria et al. (2009), when studying the Moscato Giallo cultivar with and without plastic cover. The same authors verified a higher number of bunches per plant and per square meter in the vines under plastic cover, in Flores da Cunha, RS, Brazil. Differing results were reported by other authors, such as Colombo et al. (2011), who observed that the cultivation of the BRS Clara vine under a shade cloth and plastic cover did not influence the number of bunches per plant in Marialva, PR, Brazil.

In the second evaluation year (2017/2018 crop season), a greater number of bunches on grapevines was verified without defoliation (Figure 3A), possibly occurring due to higher accumulation of reserves as a result of the lack of a defoliation operation in the previous crop season, which favors the accumulation of nutrient mobility in the previous cycle, promoting plant growth in the second cycle.

Larger bunch length and diameter were observed in vines grown under plastic cover in the 2016/2017 crop season (Table 1). This is because there is a greater water

Table 1: Mean of soluble solids (SS), bunch length (BL), bunch diameter (BD) and number of bunches per plant (NBP) in Niagara Rosada variety cultivated in Francisco Beltrão, Paraná, under two cover systems, in the 2016/2017 and 2017/2018 crop seasons

\begin{tabular}{|c|c|c|c|c|}
\hline \multicolumn{5}{|c|}{ 2016/2017 crop } \\
\hline Cover system & SS $\left({ }^{\circ}\right.$ Brix $)$ & BL (cm) & BD $(\mathbf{c m})$ & NBP \\
\hline With cover system & $14.58 \mathrm{a}^{*}$ & $15.07 \mathrm{a}$ & $7.49 a$ & $36.18 \mathrm{a}$ \\
\hline Without cover system & $13.49 \mathrm{~b}$ & $14.08 \mathrm{~b}$ & $6.88 \mathrm{~b}$ & $32.67 \mathrm{~b}$ \\
\hline $\mathrm{CV}(\%)$ & 4.78 & 8.11 & 7.26 & 7.24 \\
\hline \multicolumn{5}{|c|}{$2017 / 2018$ crop } \\
\hline Cover system & SS $\left({ }^{\circ}\right.$ Brix $)$ & $\mathrm{CC}(\mathrm{cm})$ & DC (cm) & NCP \\
\hline With cover system & $15.36^{\text {n.s. }}$ & $16.28^{\text {n.s. }}$ & $7.69^{\text {n.s. }}$ & $36.21^{\text {n.s. }}$ \\
\hline Without cover system & 15.84 & 16.47 & 7.52 & 38.73 \\
\hline $\mathrm{CV}(\%)$ & 5.42 & 5.03 & 4.12 & 9.03 \\
\hline
\end{tabular}

*Means followed by the same letter on the column do not differ statistically from each other by the Tukey test, at 5\% probability of error.
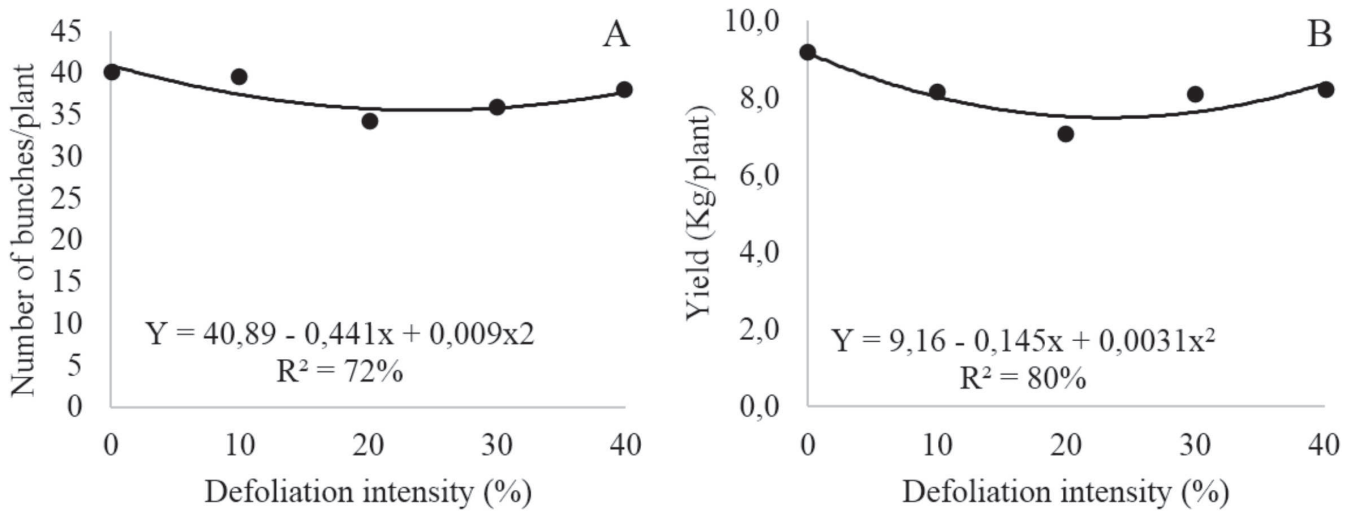

Figure 3: Number of bunches per plant (A) and yield (B) in vines of Niagara Rosada variety cultivated in Francisco Beltrão, PR, under five defoliation intensities, in the 2017/2018 crop season. 
availability for plants in the covered area, due to the restriction of solar radiation and reduced incidence of wind, which allow a lower evaporative demand and stimulate a greater stomatal opening. This fact can positively influence the growth of berries, subsequently increasing bunch diameter, due to the greater amount of water and favoring the turgor pressure, which is responsible for cell growth (Taiz \& Zeiger, 2013).

In the 2017/2018 crop season, with the greater rainfall and water availability in the soil, as well as greater relative humidity, particularly at the hottest time of the day, less evaporation occurs while maintaining higher water content in the fruits, ensuring berry growth, which has led to the absence of a significant difference between treatments.

The decrease of the active photosynthetic radiation also acts on bunch length and diameter by altering the size of the rachis and stalk. Hernandes et al. (2013) report that the decrease of the luminosity in the covered area causes a warming of the rachis and the stalk, subsequently increasing the dimensions of the bunch.

The same authors report that bunches produced in protected environments may present more berries, possibly because of the best fertilization efficiency, promoting further warming of the environment for the formation of the pollen tube, reaching the ovary and subsequently fertilizing it, in addition to the prevention of rainfall during this period, which may wash the pollen before it reaches the stigma. Another possible explanation for the higher number of berries is a greater contribution of reserves, as the leaves remain in the plants for a longer time performing a photosynthetic activity, favoring the non-abortion of the berry.

Other studies also mention the variation in bunch diameter when produced in a protected environment. Comiran et al. (2012) observed that, in the covered vineyard, bunch diameter was greater when compared to the open vineyard.

Table 2 shows the results for bunch biomass. This difference of the biomass of the curls between the treatments can be attributed, even indirectly, to the microclimatic changes provided by the plastic cover that favors the water availability of the vines, according to Cardoso et al. (2008). The same authors report that these conditions contribute to the reduction of the vapor pressure deficit, which promotes water potential and stomatal opening. Therefore, the lower evaporative demand provides a better water condition for plants and can directly favor the amount of water in the berries, which may influence the increase the size and mass of the bunches.

The photosynthetic process is benefited by the microclimate provided by the cover, and this is reflected in the increase in the biomass of the bunches. It is known that the plastic cover can attenuate stresses due to excess solar radiation or lack of water. In this case, the photosynthesis influences the increase in production (Lamas Jr, 2008).

One can also observe a mass gain between the bunches in the two years, regardless of the cover and defoliation. This increase can be attributed to more favorable environmental conditions, especially the temperature that gradually increased along the development of the bunch with maximum peak in the ripening period, without compromising the growth of the berries.

The production and productivity of vines are correlated to the number of bunches per plant and size or mass of the bunches, comprising very important variables to hybrid and hardy varieties in which high yields are a fundamental prerequisite for the production of viability (Hernandes et al., 2013).

Yield and productivity were similarly superior in vineyards under plastic cover in two crop seasons, although the 2017/2018 crop season also demonstrated a peeling effect on the production of the grapevine, which had a higher output without performing this practice.

Covered vines produced on average 6.89 and $11.46 \mathrm{~kg}$ per plant, in the 2016/2017 and 2017/2018 crop seasons, respectively, compared to $4.56 \mathrm{~kg}$ and $8.14 \mathrm{~kg}$ per plant in open vines. Although the effect of the defoliation on the increase in production is a direct result of the increase in the number of bunches, this treatment showed no effect on the final yield.

The greater yield directly reflected the final productivity of the vineyard, which was 51 and $35.5 \%$ higher in the treatment with cover in the two crop seasons studied (Table 2 ). This difference in yield between the cover and open-air environments can be explained by the micrometeorological changes provided by the plastic covering, which according to Intrigliolo \& Castel (2008), favor photosynthesis, allowing the studied vines to produce curls in greater number, diameter and length in the first crop season, in addition to crop season with a greater mass in the two cycles studied, positively resulting in greater production, with subsequent effects on the increase in productivity.

The productivity of the vines can be increased when they are cultivated in a protected environment (Hernandes et al., 2013). Comiran et al. (2012), when studying Vitis labrusca variety with and without plastic cover, obtained a yield of 4.6 and $10.2 \mathrm{~kg}$.plant ${ }^{-1}$ and a yield of 12.3 and 27.1 t.ha ${ }^{-1}$ for uncovered and covered treatments, respectively. Therefore, the yield of the covered vineyard was $54 \%$ higher than the yield in the uncovered treatment, corroborating this study.

Along with the qualitative and quantitative advantages, protected cultivation provides a guarantee of the crops, which justifies the investment in this vine protection 
technology. The plastic cover reduces the risk of occurrence of hail during the cycle, avoids the direct incidence of rainfall in the bunches, provides better environmental conditions and, mainly, facilitates the control of fungal diseases, ensuring higher yields (Hernandes et al., 2013; Pedro Júnior et al., 2011).

There was no incidence of mildew throughout the cycle in the vines under plastic cover in the two harvests. On the other hand, in the uncovered treatment, the incidence of mildew was observed only from the beginning of December in the 2016/2017 crop season, when the bunches were compacted, as shown in Table 3.

The formation of mildew spores requires $95-100 \%$ relative humidity, at least 4 hours of darkness and occurs preferably in the temperature range of $18-22{ }^{\circ} \mathrm{C}$ (Kimati, 1997). These conditions were observed during the period from December 28 to 30 in the 2016/17 crop season, especially between 04:00 am and 10:00 am (Figure 1A and 1B).

The fact that no mildew appeared in the 2017/18 crop season was due to the lack of favorable environmental conditions for its development. Once the pathogen was found, in the 2016/17 crop season, it was possible to have a better understanding of the lower yield and productivity in the discovered treatment, because, with the bunches being affected by the pathogen, the berries were detached before harvest.

Chavarria et al. (2009) describe that this change in the phytosanitary scenario is explained by the close interaction between the incidence of pathogens and the meteorological conditions, in particular the relative humidity of the air. The plastic cover changes the conditions that predispose the incidence of diseases to the 'umbrella effect', which tends to prevent the wetting of plant tissues, thereby favoring sporulation of the pathogen and infection and promoting the dispersion of the inoculum in the vineyard (Comiran et al., 2012).

Thus, by altering these environmental conditions, similar to that observed by Genta et al. (2010) and Colombo et al. (2011) in other regions, the use of the plastic cover was able to reduce the occurrence of downy mildew on Vitis labrusca variety grown in southwestern Paraná, which

Table 2: Mean of bunch biomass, yield and productivity in Niagara Rosada variety cultivated in Francisco Beltrão, PR, under cover systems, in the 2016/2017 and 2017/2018 crop seasons

\begin{tabular}{|c|c|c|c|}
\hline \multicolumn{4}{|c|}{ 2016/2017 crop } \\
\hline Cover system & Bunch biomass (g) & Yield (kg.plant ${ }^{-1}$ ) & Productivity (t. ha $\left.{ }^{-1}\right)$ \\
\hline With cover system & $191.60 \mathrm{a}^{*}$ & $6.89 a$ & $11.48 \mathrm{a}$ \\
\hline Without cover system & $139.20 \mathrm{~b}$ & $4.56 \mathrm{~b}$ & $7.6 \mathrm{~b}$ \\
\hline $\mathrm{CV}(\%)$ & 9.62 & 10.36 & 10.35 \\
\hline \multicolumn{4}{|c|}{$2017 / 2018$ crop } \\
\hline With cover system & $328.05 \mathrm{a}$ & $11.46 \mathrm{a}$ & $19.10 \mathrm{a}$ \\
\hline Without cover system & $288.42 b$ & $8.14 b$ & $14.09 \mathrm{~b}$ \\
\hline $\mathrm{CV}(\%)$ & 10.19 & 7.81 & 12.72 \\
\hline
\end{tabular}

*Means followed by the same letter on the column do not differ statistically from each other by the Tukey test, at 5\% probability of error.

Table 3: Incidence of downy mildew on Niagara Rosada variety cultivated in Francisco Beltrão, Paraná, under two cover systems, in the 2016/2017 and 2017/2018 crop seasons

\begin{tabular}{|c|c|c|c|c|c|c|c|c|}
\hline \multicolumn{9}{|c|}{ 2016/2017 crop } \\
\hline \multicolumn{9}{|c|}{ Dates } \\
\hline \multirow{2}{*}{ Cover system (CV) } & $09 / 10$ & $30 / 10$ & $21 / 11$ & $05 / 12$ & $09 / 12$ & $24 / 12$ & 21/01 & \\
\hline & L B & L B & L B & L B & L B & L B & L B & \\
\hline With CV & $-\quad-$ & $-\quad-$ & $-\quad-$ & $-\quad-$ & $-\quad-$ & $-\quad-$ & - & - \\
\hline Without CV & $-\quad-$ & $-\quad-$ & $-\quad-$ & $-\quad+$ & $+\quad+$ & $+\quad+$ & + & + \\
\hline \multicolumn{9}{|c|}{ 2017/2018 crop } \\
\hline \multicolumn{9}{|c|}{ Dates } \\
\hline \multirow{2}{*}{ Cover system (CV) } & $13 / 10$ & $27 / 10$ & $10 / 11$ & $24 / 11$ & $07 / 12$ & $22 / 12$ & \multicolumn{2}{|l|}{$03 / 01$} \\
\hline & L B & L B & L B & L B & L B & L B & $\begin{array}{ll}\mathbf{L} & \mathbf{B}\end{array}$ & \\
\hline With CV & $-\quad-$ & $-\quad-$ & $-\quad-$ & $-\quad-$ & $-\quad-$ & $-\quad-$ & $-\quad-$ & \\
\hline Without CV & $-\quad-$ & $-\quad-$ & $-\quad-$ & $-\quad-$ & $-\quad-$ & $-\quad-$ & $-\quad-$ & \\
\hline
\end{tabular}

$\mathrm{L}=$ Leaf; $\mathrm{B}=$ Bunch $++=$ presence of downy mildew; - = no mildew.

Rev. Ceres, Viçosa, v. 67, n.2, p. 137-146, mar/apr, 2020 
represents the important advance for the crop in the region, as in this locality, the rainfall level during the productive period was $632 \mathrm{~mm}$.

As pointed out by previous studies, although the incidence of downy mildew under plastic cover is reduced, phytosanitary management of plants should not be neglected. The adoption of a specific management should consider that it is possible to reduce spraying by up to $75 \%$ (Genta et al., 2010).

In summary, it can be observed that the use of the plastic cover provides a physical barrier to the action of rainfall and ultraviolet rays, controlling the mildew, enabling a reduction in the number of applications of phytosanitary products in the cultivation of the vine, and increasing production and the quality of the final product.

Based on the implementation of the cover as a crop treatment that is beneficial to the wine production, future studies can be carried out aiming at the definition of the ideal type of cover, season of installation of the cover in the vineyard, and plastic additives with a view to the handling the light incident on the plants, aiming at a higher cost-benefit ratio with the use of this technology.

\section{CONCLUSIONS}

The plastic cover, associated with the environmental conditions, can favor the physical-chemical quality of the Niagara Rosada variety.

The use of the plastic cover provides greater yield and productivity in the Niagara Rosada variety in Southwestern Paraná.

The use of the plastic cover, combined with environmental conditions and phytosanitary management, reduces the incidence of downy mildew.

The use of defoliation does not favor the cultivation of Niagara Rosada variety in southwestern Paraná.

\section{REFERENCES}

Alvares CA, Stape JL, Sentelhas PC, Gonçalves JLM \& Sparovek G (2014) Köppen's climate classification map for Brazil. Meteorologische Zeitschrift, 22:711-728.

Anzanello R, Souza PVD \& Coelho PF (2011) Desfolha em videiras americanas e viníferas na fase de pré-maturação dos frutos. Ciência Rural, 41:1132-1135.

Bettoni JC, Gardin JPP, Schumcher RL, Rodrigues OT \& Souza JA (2013) Qualidade físico-química, extração e exportação de nutrientes da cultivar Cabernet Sauvignon sobre dois porta-enxertos. Ignis, 2:41-53.

Brasil (2002) Normative instruction number 01 of February $1^{\text {st }}$, 2002. Identity and quality technical regulation for the classification of table grapes. DOU, 04/02/2002, Section 3, p.02.

Bueno TF, Villa F, Rosa DD \& Stumm DR (2017) Uso de produto à base de alho associado à poda no desempenho de videiras finas no oeste paranaense. Revista Ceres, 64:426-432.
Camargo UA, Tonietto J \& Hoffmann A (2011) Progressos na viticultura brasileira. Revista Brasileira de Fruticultura, volume especial:144-149.

Cardoso LS, Bergamaschi H, Comiran F, Chavarria G, Marodin GAB, Dalmago GA, Santos HP \& Mandelli F (2008) Alterações micrometeorológicas em vinhedos pelo uso de coberturas de plástico. Pesquisa Agropecuária Brasileira, 43:441-447.

Cardoso LS, Bergamaschi H, Comiran F, Chavarria G, Marodin GAB, Dalmago GA, Santos HP \& Mandelli F (2010) Padrões de interceptação de radiação solar em vinhedos com e sem cobertura plástica. Revista Brasileira de Fruticultura, 32:161-171.

Chavarria G, Santos HP, Mandelli F, Marodin GAB, Bergamaschi H \& Cardoso LS (2009) Potencial produtivo de videiras cultivadas sob cobertura de plástico. Pesquisa Agropecuária Brasileira, 44:141-147.

Chavarria G, Santos HP, Zanus MC, Marodin GAB, Chalaça MZ \& Zorzan C (2010) Maturação de uvas Moscato Giallo sob cultivo protegido. Revista Brasileira de Fruticultura, 32:151-160.

Colombo LA, Assis AM, Sato AJ, Tessmann DJ, Genta W \& Roberto SR (2011) Produção fora de época da videira 'BRS Clara' sob cultivo protegido. Ciência Rural, 41:212-218.

Comiran F, Bergamaschi H, Heckler BMM, Santos HP, Alba D \& Saretta E (2012) Microclima e produção de videiras 'Niagara Rosada' em cultivo orgânico sob cobertura plástica. Revista Brasileira de Fruticultura, 34:152-159.

Detoni AM, Clemente C \& Fornari C (2007) Produtividade e qualidade da uva 'Cabernet Sauvignon' produzida sob cobertura de plástico em cultivo orgânico. Revista Brasileira de Fruticultura, 29:530-534.

Embrapa - Empresa Brasileira de Pesquisa Agropecuária (2006) Sistema Brasileiro Classificação de Solos. $2^{a}$ ed. Rio de Janeiro, Embrapa - SPI. 306p.

Ferreira DF (2011) Sisvar: um computador sistema de análise estatística. Ciência \& Agrotecnologia, 35:1039-1042.

Fogaça AL, Daudt CE \& Dorneles F (2007) Potássio em uvas II análise peciolar e sua correlação com o teor de potássio em uvas viníferas. Ciência e Tecnologia de Alimentos, 27:597-601.

Genta W, Tessmann DJ, Roberto SR, Vida JB, Colombo LA, Scapin CR, Ricce WS \& Clovis LR (2010) Manejo de míldio no cultivo protegido de videira de mesa 'BRS Clara'. Pesquisa Agropecuária Brasileira, 45:1388-1395.

Hernandes JL, Pedro Júnior MJ, Blain GC \& Rolim GS (2013) Comportamento produtivo da videira 'Niagara Rosada' em diferentes sistemas de condução, com e sem cobertura plástica, durante as safras de inverno e de verão. Revista Brasileira de Fruticultura, 35:123-130.

IAL - Instituto Adolfo Lutz (2008) Métodos físico-químicos para análises de alimentos. $4^{\mathrm{a}}$ ed. São Paulo, Instituto Aldolfo Lutz. $1018 \mathrm{p}$.

IBGE - Instituto Brasileiro de Geografia e Estatística. Levantamento sistemático da produção agrícola. Avaiable at: < http:// www.ibge.gov.br>. Accessed on: February 18 ${ }^{\text {th }}, 2016$.

Intrigliolo DS \& Castel JR (2008) Effects of irrigation on the performance of grapevine cv. Tempranillo in Requena, Spain. American Journal of Enology and Viticulture, 59:30-38.

Kimati H, Amorim L, Bergamim Filho A, Camargo LEA \& Rezende JAM (1997) Manual de Fitopatologia. $3^{a}$ ed. São Paulo, Agronômica Ceres. 686p.

Kishino AY, Carvalho SLC \& Roberto SR (2007) Viticultura tropical: o sistema de produção do Paraná. Londrina, IAPAR. $366 \mathrm{p}$. 
Lamas Júnior GLC (2008) Ecofisiologia e fitotecnia do cultivo protegido de videiras cv. Moscato Giallo (Vitis vinifera L.). 136p Tese (Doutorado em Fitotecnia) - Universidade Federal do Rio Grande do Sul.

Maia JDG \& Camargo UA (2012) O cultivo da videira Niagara no Brasil. Brasília, Embrapa. 301p.

Miele A, Rizzon LA \& Mandelli F (2009) Manejo do dossel vegetativo da videira e seu efeito na composição do vinho Merlot. Pesquisa Agropecuária Brasileira, 44:463-470.

Neis S, Reis EF \& Santos SC (2010) Produção e qualidade da videira cv. Niagara Rosada em diferentes épocas de poda no sudoeste goiano. Revista Brasileira Fruticultura, 32:1146-1153.

Pedro Júnior MJ, Hernandes JL \& Rolim GS (2011) Sistema de condução em Y com e sem cobertura plástica: microclima, produção, qualidade do cacho e ocorrência de doenças fúngicas na videira 'Niagara Rosada'. Bragantia, 70:228-233.

Pötter GH, Daudt CE, Brackamnn A, Leite TT \& Penna NG (2010) Desfolha parcial em videiras e seus efeitos em uvas e vinhos Cabernet Sauvignon da região da Campanha do Rio Grande do Sul, Brasil. Ciência Rural, 40:2011-2016.
Radünz AL, Schöffel ER, Hallal MOC \& Brixner GF (2013) Efeito da época de poda e da desfolha na interceptação de radiação solar na videira Bordô. Bragantia, 72:403-407.

Roberto SR, Colombo LA \& Assis AM (2011) Cultivo protegido em viticultura. Ciência e Técnica Vitivinícola, 26:11-16.

Souza ER, Ribeiro VG \& Pionório JAA (2012) Intensidades de desfolha para qualidade de cachos da videira "Superior Seedless" no ‘Submédio' São Francisco. Pesquisa Aplicada e Agrotecnologia, Guarapuava, 5:87-98.

Taiz L \& Zeiger E (2013) Fisiologia Vegetal. 5 ed. Porto Alegre, Artmed. 918p

Yamamoto LY, Assis AM, Morais HY, Souza FS, Scapin CR, Tessmann DJ, Souza RT \& Roberto SR (2012) Produção e características físico-químicas dos cachos da videira 'BRS Clara' sob cobertura plástica e sombrite em safra fora de época. Revista Brasileira de Fruticultura, 34:160-166.

Zarth NA, Citadin I, Perodin MA \& Donazzolo J (2011) Perfil sócio econômico da vitivinicultura na região Sudoeste do Paraná. Synergismus scyentifica UTFPR, 6:01-10.

Yara - Programas nutricionais Yara Brasil (2008) Fornecendo as melhores soluções. São Paulo, Yara Brasil. 57p. 